\title{
Alcohol-based hand rub consumption surveillance in German hospitals - latest results
}

\author{
M Behnke*, JO Clausmeyer, C Reichardt, P Gastmeier \\ From 3rd International Conference on Prevention and Infection Control (ICPIC 2015) \\ Geneva, Switzerland. 16-19 June 2015
}

\section{Introduction}

HAND-KISS is a unit-based surveillance system of alcohol-based hand rub consumption (AHC). It is part of the German national nosocomial infection surveillance system (KISS).

\section{Objectives}

We analyzed the development in AHC between 2007 to 2014.

\section{Methods}

Participating hospitals transfer data on patient days and AHC per unit once a year to HAND-KISS. The system calculates the data as AHC in milliliter $(\mathrm{ml})$ per patient day (PD) stratified by unit type (intensive care units [ICU] and non-ICU) and specialty (medical, surgical, pediatrics, neonatal etc.). The distribution of all participating wards are published annually as HAND-KISS reference data.

To evaluate AHC changes over the years, we selected all hospitals and wards which continuously provided surveillance data over the whole period of 8 years. For all ICUs and non-ICUs we estimated the median AHC (interquartile range, IQR) for every year and compared the results.

\section{Results}

188 hospitals with 334 ICUs and 1,954 non-ICUs transferred AHC data for 2007 (645 hospitals, 890 ICUs and 6,063 non-ICUs for 2014[g1]). 101 hospitals with 130 ICUs and 760 non-ICUs continuously provided surveillance data over a period of 8 years.

In 2007, the median AHC in the ICUs was $69 \mathrm{ml} / \mathrm{PD}$ (IQR, $52 \mathrm{ml} / \mathrm{PD}-95 \mathrm{ml} / \mathrm{PD}$ ), and in 2014 the result was $115 \mathrm{ml} / \mathrm{PD}(\mathrm{IQR}, 84 \mathrm{ml} / \mathrm{PD}-140 \mathrm{ml} / \mathrm{PD})$ corresponding

$$
\text { Institute of Hygiene and Environmental Medicine, Charité - University }
$$$$
\text { Medicine Berlin, Berlin, Germany }
$$

Submit your next manuscript to BioMed Central and take full advantage of:

- Convenient online submission

- Thorough peer review

- No space constraints or color figure charges

- Immediate publication on acceptance

- Inclusion in PubMed, CAS, Scopus and Google Scholar

- Research which is freely available for redistribution 